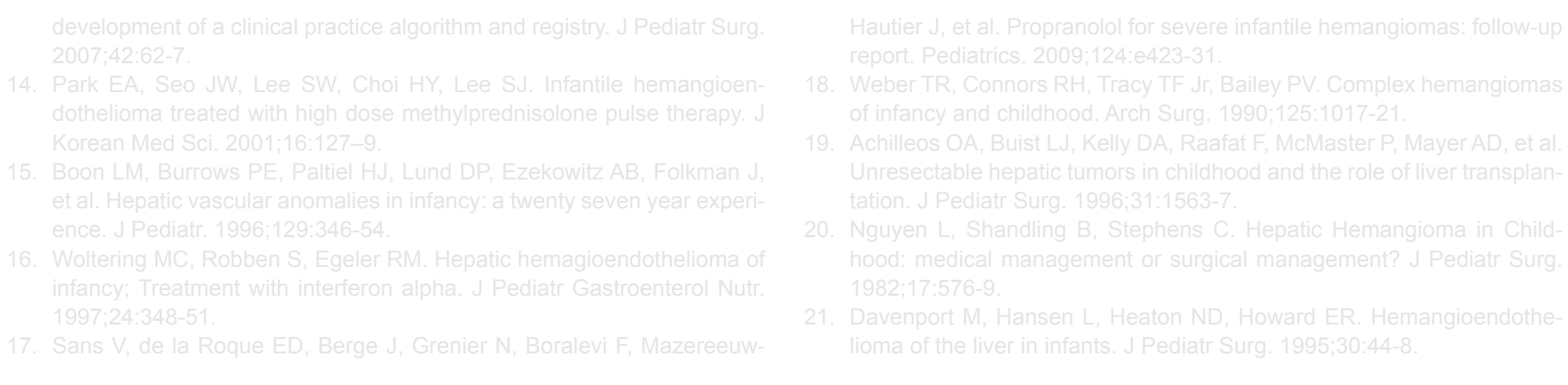

\title{
A Rare Case of Mucormycosis in the Scalp
}

\author{
Um Caso Raro de Mucormicose no Couro Cabeludo
}

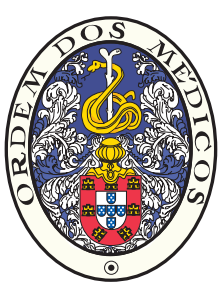

\author{
Mehmet HARMAN ${ }^{1}$, Derya UÇMAK ${ }^{1}$, Tuba DAL ${ }^{2}$ \\ Acta Med Port 2013 Nov-Dec;26(6):754-757
}

\section{ABSTRACT}

Introduction: Mucormycosis is a rapidly progressive and frequently lethal form of fungal infection. Primary cutaneous form is rare. We presented a case of cutaneous mucormycosis in the scalp which led to visual loss in a 54-year-old diabetic woman.

Case Presentation: A 54-year-old woman patient was admitted with the complaining of the wound with purulent discharge in the scalp. An ulcerated discharging lesion with necrotic hemorrhagic crusts in the left parietal region of the scalp and wheals with fluctuating from this lesion to the left periorbital area were observed. Biochemical investigations revealed elevated blood sugar level and urine ketone bodies were present. The patient had vision loss in the left eye. In the smears thick-walled non-septate hyphae were detected. Rhizopus spp. was isolated from culture. Antidiabetic therapy and liposomal amphotericin B was initiated. The scalp lesion improved.

Conclusion: Early diagnosis is life saving in mucormycosis.

Keywords: Diabetes Mellitus/ complications; Mucormycosis; Scalp; Scalp Dermatoses.

\section{RESUMO}

Introdução: A mucormicose é uma infecção fúngica rapidamente progressiva e frequentemente letal. A forma cutânea primária é rara. Apresentamos um caso de mucormicose cutânea da região do couro cabeludo cuja evolução conduziu a um quadro de perda de visão numa mulher diabética de 54 anos de idade.

Caso Clínico: Uma doente de 54 anos de idade foi internada com uma lesão cutânea do couro cabeludo com drenagem purulenta. À observação, a doente apresentava uma lesão ulcerada supurativa com crostas hemorrágicas necróticas localizada na região parietal esquerda, com formação de pápulas e um processo de flutuação estendendo-se para a região periorbitária esquerda. As análises revelaram a presença de hiperglicemia e cetonúria. A doente apresentava perda de visão do olho esquerdo. No esfregaço era possível observar a presença de hifas de parede espessada não septadas. Foram isolados no exame cultural fungos do género Rhizopus spp. Foi iniciada terapêutica antidiabética e anfotericina B lipossómica. A lesão do couro cabeludo teve uma evolução favorável.

Conclusão: O diagnóstico precoce é decisivo na mucormicose.

Palavras-chave: Mucormicose; Diabetes Mellitus/ complicações; Dermatoses do Couro Cabeludo.

\section{INTRODUCTION}

Mucormycosis is a rare opportunistic fungal infection caused by the Zigomycetes Class, and genus of Mucorales. ${ }^{1}$ The most common pathogenic agents are Rhizopus, Rhizomucor, Mucor, and Absidia. These organisms generally found in soil and plants. ${ }^{2}$ Mucormycosis was recognized as one of the most rapidly progressive lethal form of fungal infection in humans with a high mortality of $25-62 \%{ }^{1}$

Patients with diabetic ketoacidosis are at high risk of developing mucormycosis. There is plenty of evidence to support the conclusion that cases with systemic acidosis have elevated serum iron levels, likely due to release of iron from binding proteins in the presence of acidosis. ${ }^{3}$ Mucormycosis can also encountered in patients with immunodeficiency, neutropenia, severe burns, and severe iron loading and the incidence of this infection increases in hematologic malignancies, bone marrow transplantation, post-chemotherapy, and steroid therapy. ${ }^{2,4}$ Especially uncontrolled diabetes mellitus, and trauma are the most common risk factors for mucormycosis. ${ }^{5,6}$ Based on clinical presentation and involvement of a particular anatomic site, mucormycosis can be divided into at least six clinical categories such as rhinocerebral, pulmonary, cutaneous, gastrointestinal,

1. Department of Dermatology. Faculty of Medicine. Dicle University. Diyarbakir. Turkey.

2. Department of Microbiology and Clinical Microbiology. Faculty of Medicine. Dicle University. Diyarbakir. Turkey.

Recebido: 11 de Fevereiro de 2013 - Aceite: 09 de Setembro de 2013 | Copyright @ Ordem dos Médicos 2013 


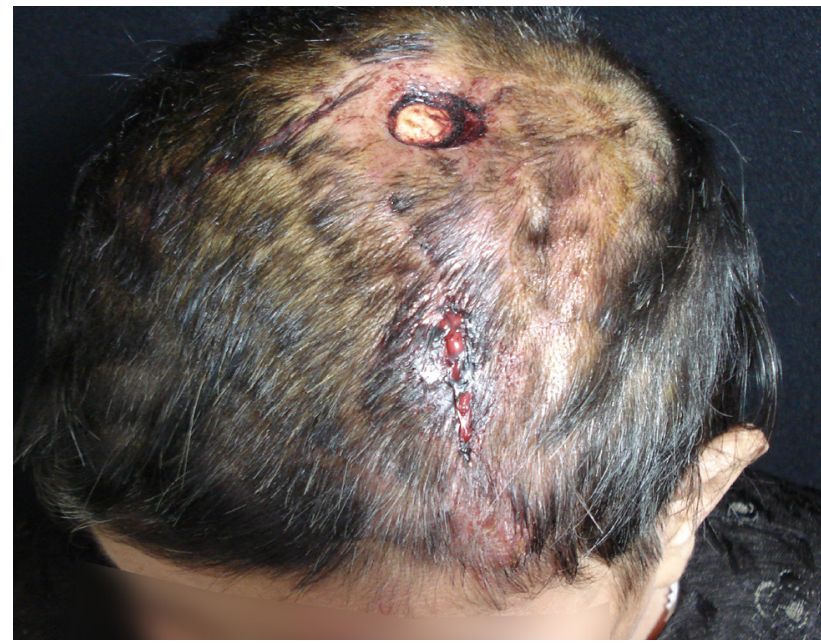

Figure 1 - Ulcerated lesion with purulent discharge of the scalp.

disseminated, and miscellaneous. ${ }^{4}$ Rhinocerebral mucormycosis is the most common form of the disease and may spread to orbit. ${ }^{4,7}$ There were a few cases of cutaneous mucormycosis beginning directly without any focus in the literature but the infection was frequently seen in extremities of the patients. ${ }^{8,9}$ In current article we presented a case with cutaneous mucormycosis in the scalp led to visual loss in a 54-year-old diabetic female and we aimed to emphasize the importance of early diagnosis and treatment in cutaneous mucormycosis.

\section{CASE}

A 54-year-old woman patient was admitted to Dermatology Clinic of Dicle University Medical Faculty Hospital with the complaining of the wound with discharge in the scalp. In patient's medical history, the patient had no known disease. She described a small wound occurred on the scalp about one year ago and she stated that antibiotic treatment was started many times by doctors but her complaints did not decline. The patient had loss of vision in the left eye for two months. In dermatological examination, it was observed that an ulcerated discharging lesion with necrotic hemorrhagic crusts in the left parietal region of the scalp $2 \times 2 \mathrm{~cm}$ in diameter and wheals with fluctuating from this lesion to the left periorbital area (Fig. 1). The patient was hospitalized in our clinic. Biochemical investigations revealed elevated blood sugar level and urine ketone bodies were detected. the Arterial Blood Gas (ABG) analysis indicated a state of severe uncompensated metabolic acidosis. The patient's systemic examination of cardiovascular, pulmonary and gastrointestinal system was normal. On the ophthalmological examination, patient had vision loss in her left eye. On orbital magnetic resonance (MR) imaging, thickening of the left temporal and left parietal scalp into the orbital images, increased signal intensity on T2-weighted sequences and contrast enhancement, in retro-orbital adipose tissue growth, heterogeneous hyperintense signal increase, thickening of left superior rectus muscle on STIR sequence, heterogeneity, irregularity, and peripheral contrast enhance-

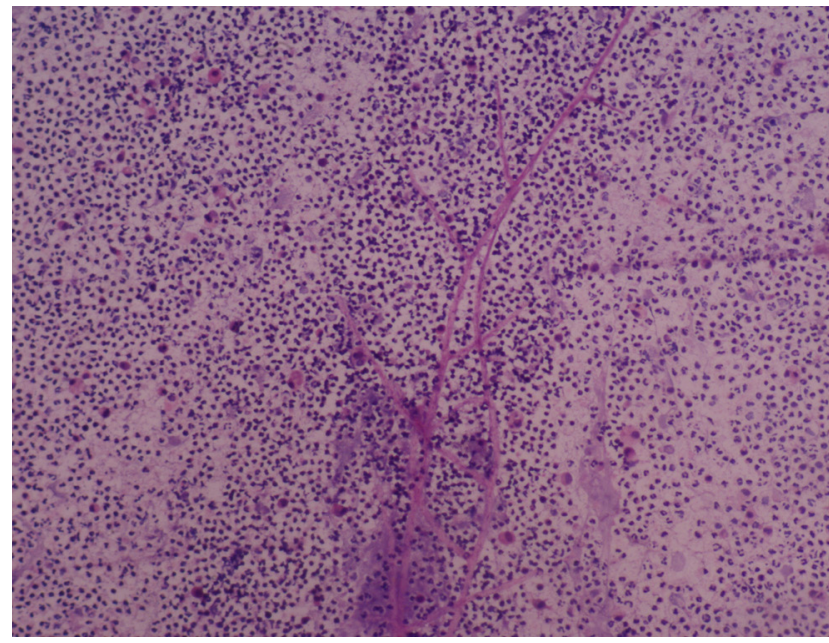

Figure 2 - Thick-walled septate hyphae in the smear of purulent material (giemsa, original magnification $\times 100)$.

ment, and in the periorbital soft tissues, the presence of small lesions compatible with abscess formation having peripheral contrast enhancement were observed.

Cranial Computed Tomography (CT) indicated soft tissue densities having peripheral contrast enhancement and central hypodense area extending from the left superior frontal region to periorbital soft tissue and intraorbital area causing exophthalmos in the left eye. Left occipital and temporal regions showed similar views. Thickening and enhancement increase were observed in the left superior rectus muscle. Air was detected in superior frontal area of skin and subcutaneous tissue. In addition there were no opacification in the paranasal sinuses and the sinus mucosa was normal on CT.

A skin biopsy was performed in order to obtain the histopathological examination and a tissue culture was taken. In the smears, neutrophils, plasma cells and thick-walled non-septate hyphae showed irregular width with right angle branching (Fig. 2) were observed. The samples were inoculated on two Sabouraud Dextrose Agar (SDA) media for culturing and one of the media incubated at $37^{\circ} \mathrm{C}$ and the other at $25^{\circ} \mathrm{C}$ for 24 hours. After the fourth day of incubation the mold colonies were seen on the surface of the media. Cultivated mold was defined based on morphological features of colonies (cotton-candy like) and microbiological characteristics. With staining with lactophenol cotton blue, nonseptate broad hyphae, sporangiophores, rhizoids (root-like hyphae), sporangia, and sporangiospores were visualized. Sporangiophores were brown in color and mold was identified as Rhizopus spp (Fig. 3). Furthermore, the patient was diagnosed as mucormycosis, histopathologically. Based on CT imaging the differential diagnosis of rhinocerebral mucormycosis was ruled out and according to obtained examinations the patient was considered to be diabetic ketoacidosis-related mucormycosis. Antidiabetic therapy (Humalog ${ }^{\circledR}, 12 / 12 / 12 \mathrm{U}$ and Lantus ${ }^{\circledR}, 36 \mathrm{U}$ ) and liposomal amphotericin B (Abelcet ${ }^{\circledR}$ flacon $375 \mathrm{mg} /$ day) was initiated for the patient. After removal of necrotic tissue, local wound care with fusidic acid, chlorhexidine were per- 


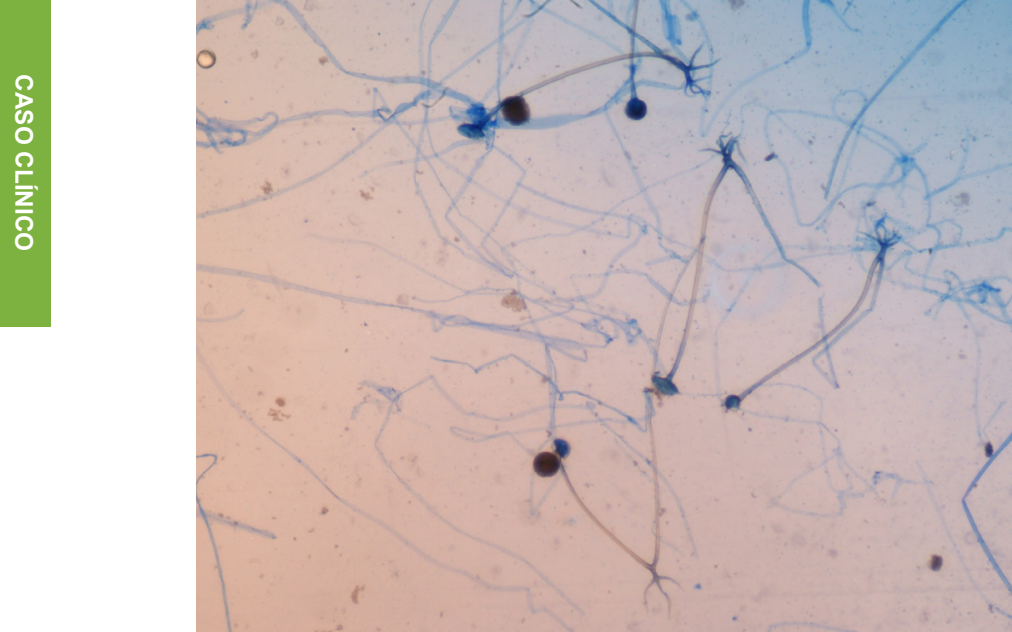

Figure 3 - Lactophenol cotton blue staining of cultivated mold (original magnification $\times 100)$.

formed. Magnetic resonance imaging findings of retroorbital and periorbital involvements regressed in third week of treatment, dramatically. However vision loss was persistent due to damage of optic nerve. Scalp lesion improved (Fig. 4 ) and the patient was discharged on the fourthieth day of amphotericin B therapy.

\section{DISCUSSION}

Mucormycosis is manifested by a variety of different syndromes in humans, predominantly in immunocompromised patients and those with diabetes mellitus. Although mucormycosis is a rare infection in the general population, exposure to mucor species is common. The acquisition of mucormycosis infection in humans usually occurs by fungal spores in the air. Among clinical forms of mucormycosis pulmonary and rhinocerebral involvements are the most common. Primary cutaneous form of mucormycosis is a rare form. ${ }^{10}$

Development of diabetes mellitus was reported as a predisposing factor in $36 \%-88 \%$ of the cases. Uncontrolled hyperglycaemic patients and especially patients with ketoacidosis were highly susceptible to mucormycosis infection. Sometimes mucormycosis may be the first sign of undiagnosed diabetes and rarely this infectious disease was encountered in patients with controlled diabetes mellitus. ${ }^{5}$ Laboratory investigations of our case revealed elevated blood sugar level and urine ketone bodies and the patient had an undiagnosed diabetes mellitus, in accordance with the literature.

Primary cutaneous mucormycosis is a disease showing acute rapid progressive course with high mortality. Cutaneous mucormycosis occurred by inoculation of fungal spores directly to the skin, that this may lead to disseminated disease. Opposite of this transmission, i.e., spread from internal organs to skin is a very rare form. Roden et al. reported only 6 patients indicating transition in this way. ${ }^{11}$ Accordingly, only the skin or subcutaneous tissue can be invaded. When there is a deep invasion, infection can proceed to the muscles, tendons, bone, and may be disseminated. ${ }^{5}$

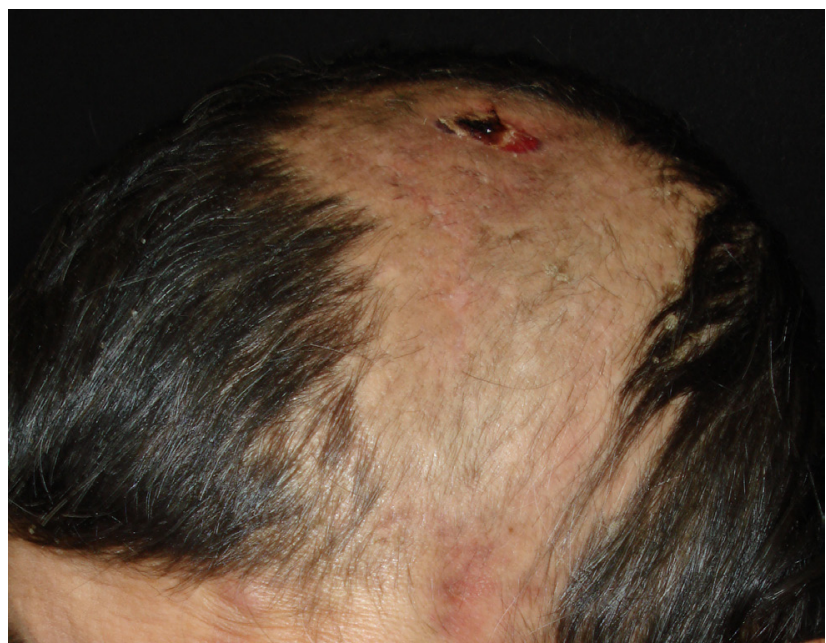

Figure 4 - Post-treatment imaging of the patient.

Primary cutaneous and subcutaneous infections usually the result of a 'barrier break' or traumatic implantation of fungal elements. Rubber bands, or intravenous catheter sites were usually responsible from transition to the penetration field. Therefore lesions placed in the extremities and upper part of trunk. ${ }^{4}$ Typical clinical appearance of cutaneous mucormycosis is a necrotic eschar tissue surrounded by erythema and infiltration. However sometimes small and not significant nonspecific erythematous macules may be a sign of disseminated disease in immunosuppressive patients. Mucormycosis with necrotic eschar can mimic pyoderma gangrenosum, bacterial synergistic gangrene, and other infectious diseases caused by bacteria or fungi. ${ }^{5}$ In current article we presented a case with cutaneous mucormycosis in scalp. An ulcerated discharging lesion with necrotic hemorrhagic crusts in the left parietal region of the scalp and invasion to the left periorbital area was seen in our case. In our case, despite the long duration of the infection the formation of gangrene was not seen and the disease was proceed slowly. Our case was considered as subcutaneous form of primary mucormycosis. If the patient has been diagnosed in early period, secondary complication would not improve.

The definitive diagnosis of mucormycosis is performed by direct microscopic examination, culture and histopathologically. In histopathologic examination, oedema, necrosis, polymorph nuclear cells, plasma cells, granulation tissue, thrombosis, and vascular infarct are observed, ${ }^{4}$ For the definitive diagnosis of these cases as soon as possible, dermatologists must be in cooperation with microbiology and pathology laboratories.

Early diagnosis, the patient's immune status and accompanying factors play significant roles in successful treatment of patients with mucormycosis. The use of amphotericin- $B$ is highly effective for the treatment of cutaneous lesions as in our case. In our case, despite the visual loss, deepening of invasion was prevented by the treatment of Amphotericin B, and the patient's life was saved. However Melsom et al. were presented a case with non-insulin 
dependent diabetes mellitus who died despite treatment with intravenous Amphotericin B. ${ }^{6}$ A case of primary cutaneous mucormycosis in a malnourished infant was presented in Turkey. This infection progressed rapidly, and the infant died from infection and the diagnosis was made at postmortem examination. ${ }^{12}$ For the treatment of this progressive infections, aggressive surgical debridement may also be necessary, due to Amphotericin $B$ does not penetrate devascularized tissue. ${ }^{4}$ The other drug, posaconazole has enhanced in vitro activity against the Mucorales, with reported $90 \%$ minimum inhibitory concentrations (MIC90) of 1 to $>4 \mu \mathrm{g} / \mathrm{Ml} .{ }^{13}$ However pharmacokinetic and pharmacodynamic data raise concerns about the reliability of achieving adequate in vivo levels of oral posaconazole to treat mucormycosis. Sun et al. detected that posaconazole was significantly less effective than AmB in neutropenic mice infected with Mucor species. ${ }^{14}$ Dannaoui et $\mathrm{al}^{15}$ also reported that posaconazole was less effective than Amphotericin $B$, in treating mice infected with Rhizopus microsporus or Absidia species. On the basis of the available data, monotherapy cannot be recommended as primary treatment of mucormycosis. However, some studies suggested that posaconazole is a reasonable option for patients with mucormycosis who are refractory to or intolerant of polyenes. ${ }^{16,17}$ It was reported that combining posaconazole with Amphotericin
$B$ had no advantage, compared with a standard dosage of Amphotericin B monotherapy. ${ }^{18,19}$ Furthermore, hyperbaric oxygen therapy has been used with some benefit. ${ }^{6}$ Diagnostic imaging has important implications for the need for and extent of surgical debridement, and for prognosis. ${ }^{6}$

\section{CONCLUSION}

In conclusion, cutaneous involvement of mucormycosis is rare. Early diagnosis and early treatment is life saving. Clinical, histopathological, examination, imaging and also microbiological examination and culture play important roles on early diagnosis of cutaneous infections caused by Mucor.

\section{CONFLICT OF INTERESTS}

The authors stated that they have no commercial associations, contractual relations, or proprietary considerations that might pose a conflict of interest related or unrelated with the submitted manuscript, and have had no involvements that might raise the question of bias in the work reported or in the conclusions, implications, or opinions stated.

\section{FUNDING SOURCES.}

\author{
None stated.
}

\section{REFERENCES}

1. Khatiwada P, Giri A, Khatiwoda P. Mucormycosis in diabetes mellitus. J Advances Intl Med. 2012;1:73-5.

2. Pak J, Tucci VT, Vincent AL, Sandin RL, Greene JN. Mucormycosis in immunochallenged patients. J Emerg Trauma Shock. 2008;1:106-13.

3. Spellberg B, Edwards J, Ibrahim A. Novel perspectives on mucormycosis: Pathophysiology, presentation, and management. Clin Microbiol Rev. 2005;18:556-69.

4. Perusquía-Ortiz AN, Vázquez-González D, Bonifaz A. Opportunistic filamentous mycoses: aspergillosis, mucormycosis, phaeohyphomycosis and hyalohyphomycosis. J Dtsch Dermatol Ges. 2012;10:611-21.

5. Petrikkos G, Skiada A, Lortholary O, Roilides E, Walsh TJ, Kontoyiannis DP. Epidemiology and clinical manifestations of mucormycosis. Clin Infect Dis. 2012;54:23-34.

6. Melsom S, Khangure M. Craniofacial mucormycosis following assault: An unusual presentation of an unusual disease. Australas Radiol. 2000;44:104-6.

7. Hadzri MH, Azarisman SM, Fauzi ARM, Kahairi A. Invasive rhinocerebral mucormycosis with orbital extension in poorly- controlled diabetes mellitus. Singapore Med J. 2009;50:107-9.

8. Arnáiz-García ME, Alonso-Peña $D$, del Carmen González-Vela $M$, García-Palomo JD, Sanz-Giménez-Rico JR, Arnáiz-García AM. Cutaneous mucormycosis: report of five cases and review of the literature. J Plast Reconstr Aesthet Surg. 2009;62:434-41.

9. Larché J, Machouart M, Burton K, Collomb J, Biava MF, Gé A, et al. Diagnosis of cutaneous mucormycosis due to rhizopus microsporus by an innovative PCR-restriction fragment-length polymorphism method. Clin Infect Dis. 2005;41:1362-5.

10. Sugar AM. Mucormycosis. Clin Infect Dis. 1992;14:126-9.

11. Roden MM, Zaoutis TE, Buchanan WL, Knudsen TA, Sarkisova TA,
Schaufele RL, et al Epidemiology and outcome of mucormycosis: a review of 929 reported cases. Clin Infect Dis. 2005;41:634-53.

12. Koklu E, Akcakus M, Torun YA, Tulpar S, Tasdemir A. Primary gangrenous cutaneous mucormycosis of the scalp in a child: a case report. Pediatr Emerg Care. 2008;24:102-4.

13. Goldstein EJ, Spellberg B, Walsh TJ, Kontoyiannis DP, Edwards J, Ibrahim AS. Recent advances in the management of mucormycosis: From bench to bedside. Clin Infect Dis. 2009;48:1743-51.

14. Sun QN, Fothergill AW, McCarthy DI, Rinaldi MG, Graybill JR. In vitro activities of posaconazole, itraconazole, voriconazole, amphotericin $B$, and fluconazole against 37 clinical isolates of zygomycetes. Antimicrob Agents Chemother. 2002;46:1581-2.

15. Dannaoui E, Meis JF, Loebenberg D, Verweij PE. Activity of posaconazole in treatment of experimental disseminated zygomycosis. Antimicrob Agents Chemother. 2003;47:3647-50.

16. van Burik JA, Hare RS, Solomon HF, Corrado ML, Kontoyiannis DP. Posaconazole is effective as salvage therapy in zygomycosis: a retrospective summary of 91 cases. Clin Infect Dis. 2006;42:61-5.

17. Greenberg RN, Mullane K, van Burik JA, Raad I, Abzug MJ, Anstead $\mathrm{G}$, et al. Posaconazole as salvage therapy for zygomycosis. Antimicrob Agents Chemother. 2006;50:126-33

18. Rodriguez MM, Serena C, Marine M, Pastor FJ, Guarro J. Posaconazole combined with amphotericin $\mathrm{B}$, an effective therapy for a murinedisseminated infection caused by Rhizopus oryzae. Antimicrob Agents Chemother. 2008;52:3786-8.

19. Ibrahim AS, Gebermariam T, Schwartz JA, Edwards JE Jr, Spellberg B. Posaconazole mono- or combination therapy for the treatment of murine zygomycosis. Antimicrob Agents Chemother. 2009;53:772-5. 
Mehmet HARMAN, Derya UÇMAK, Tuba DAL

\section{A Rare Case of Mucormycosis in the Scalp}

Acta Med Port 2013:26:754-757

Publicado pela Acta Médica Portuguesa, a Revista Científica da Ordem dos Médicos

Av. Almirante Gago Coutinho, 151

1749-084 Lisboa, Portugal.

Tel: +351218428 215

E-mail: submissao@actamedicaportuguesa.com

www.actamedicaportuguesa.com

ISSN:0870-399X | e-ISSN: 1646-0758

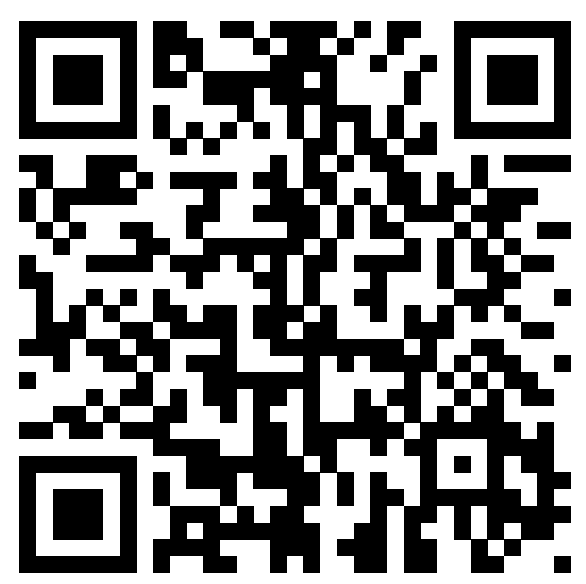

ACTA MÉDICA

PORTUGUESA 